$\frac{52}{4-10}-950+5(2)$

PREPARED FOR THE U.S. DEPARTMENT OF ENERGY, UNDER CONTRACT DE-AC02-76-CHO-3073

\title{
MEASUREMENTS OF DT AND DD NEUTRON YIELDS BY NEUTRON ACTIVATION ON TFTR
}

PPPL-3054

PPPL-3054

UC-420,426

\author{
BY
}

C.W. BARNES, A.R. LARSON, G. LEMUNYAN, ET AL.

MARCH 1995

mincerton

masna myrones

LAConatory

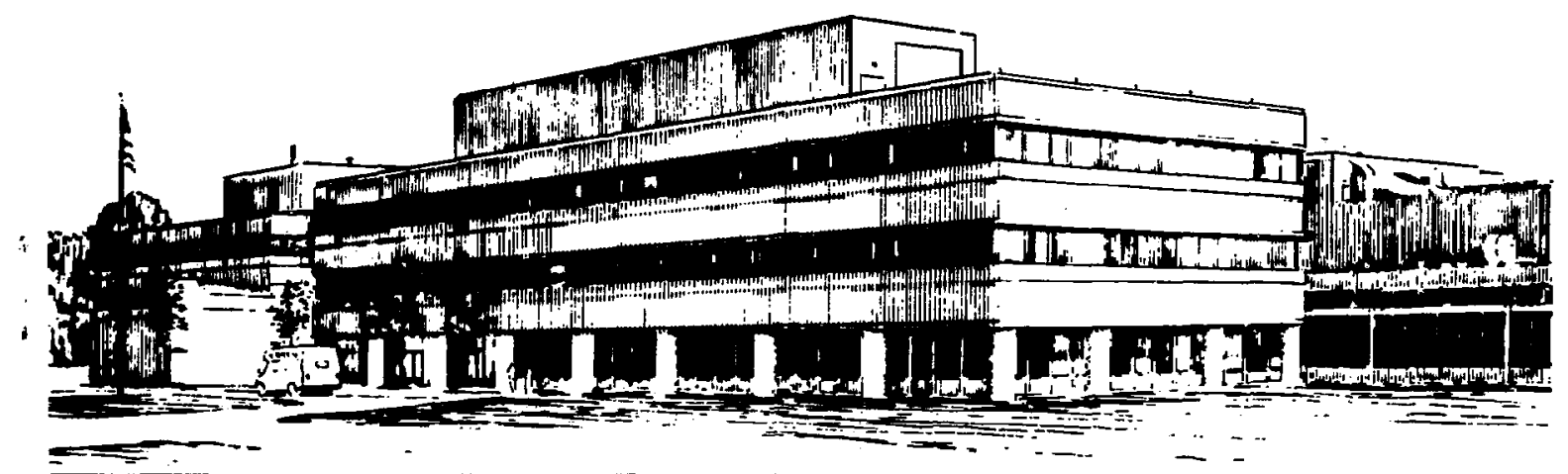

\section{PRINCETON}


This report was prepared as an account of work sponsored by an agency of the United States Govermment. Neither the United States Government nor any agency thereof, nor any of their employees, makes any warranty, express or implied, or assumes any legal liability or responsibility for the accuracy, completeness, or usefulness of any information, apparatus, product, or process disclosed, or represents that its use would not infringe privately owned rights. Reference herein to any specific commercial produce, process, or service by trade name, trademark, manufacturer, or otherwise, does not necessarily constitute or imply its endorsement, recommendetion, or favoring by the United States Government or any agency thereot. The views and opinions of authors expressed herein do not necessarily state or reflect those of the United States Government or any agency thereof.

\section{NOTICE}

This report has been reproduced from the best available copy. Available in paper copy and microtiche.

Number of pages in this report: 17

DOE and DOE contractors can obtain copies of this report from:

Office of Scientific and Technical Information

P.O. Box 62

Oak Ridge, TN 37831;

(615) 576-8401.

This report is publicly available from the:

National Technical Information Service

Department of Commerce

5285 Port Royal Road

Springfield, Virginia 22161

(703) $487-4650$ 
May 5. 1994

\title{
Measurements of DT and DD Neutron Yields by Neutron Activation on TFTR
}

\author{
Cris W. Barnes. Alvin R. Larson \\ Los Alamos Vational Laboratory \\ G. Le:Munyan \\ Princeton Plasma Physics Laboratory \\ and M. J. Loughlin \\ JET Joint lindertaking
}

\begin{abstract}
A variety of elemental foils have been activated by neutron fluence from TFTR under conditions with the DT neutron yield per shot ranging from $10^{12}$ to over $10^{18}$. and with the $\mathrm{DT} /(\mathrm{DD}+\mathrm{DT}$ ) neutron ratio varying from $0.5 \%$ (from triton burnup) to unity. Linear response over this large dynamic range is obtained by reducing the mass of the foils and increasing the cooling time. all while accepting greatly improved counting statistics. Effects on background gamma-ray lines from foil-capsule-material contaminants, and the resulting lower limits on activation foil mass. have been determined. DT neutron sieids from dosimetry standard reactions on aluminum. chromium, iron. nickel. zirconjum. and indium are in agreement ithin the $59 \%$ (one-sigma) accuracy of the measurements: also agreeing are yields from silicon foils using the ACTL library cross-section. while the ENDF/B-V library has too low a cross-section. Preliminary results from a variety of other threshold reactions are presented. Cise of the ${ }^{115} \ln \left(n . n^{\circ}\right)^{115 m}$ In reaction $(0.42$ times as sensitive to DT neutrons as DD neutrons) in conjunction with pure-DT reactions allows a determination of the $\mathrm{DT} /(\mathrm{DD}+\mathrm{DT})$ ratio in trace tritium or low-power tritium beam experiments.
\end{abstract}




\section{Introduction}

The highest accuracy determinations of neutron yields and fusion energy production tave been provided by nuclear activation techniques. ${ }^{2}$. Veutron activation has been used to measure triton burnup in tokamaks ${ }^{2-5}$ : it was also used to measure the high DT yields during the Preliminary Tritium Experiments on JET in 1991. This work reports measurements of neutron activation during the DT Program on the Tokamak Fusion Test Reactor (TFTR) between November, 1993 and April, 1994. Neutron activation measurements on TFTR use a computer-controlled pneumatic transfer system. ${ }^{6.7}$ While "backup" measurements generally using silicon foils ${ }^{8}$ were made at irradiation ends outside the vacuum vessel. all the results of this paper involve elemental foils irradiated at a re-entrant location inside the top of the vessel. ${ }^{9}$

The absolute calibration for converting neutron activation to yield has five components. 1) The mass of the elemental foil is determined from a Mettler H33AR balance calibrated annually; the composition of the high-purity foils is given by the manufacturer. 2) The full-energy-peak efficiency of the high purity Germanium (HPGe) detectors' has been updated by use of a NIST-traceable radioactive source ${ }^{10}$ and calculations of the self-shielding of the foils using standard attenuation factors. ${ }^{11.12}$ 3) A standard reference ${ }^{13}$ is used for the nuclear coefficients. 4) The cross-sections are from the ACTL library ${ }^{24}$ : in the case of aluminum it has been normalized by $2 \%$ to the standard values from Ref. 15 . 5) Finally. a 3dimensional neutronics calculation using the MCNP code ${ }^{16}$ is performed to determine the scattering and attenuation at the irradiation location and determine the ratio of energy-weighted fluence to yield from TFTR plasmas. ${ }^{9}$ The overall accuracy in the determination of the DT neutron yield is $\pm 8 \%$ (one-sigma) not including any uncertainties in the cross-section. nuclear coefficients (isotopic abundance or gammaray branching ratio). or counting statistics of particular reactions. ${ }^{9}$

\section{Operational Effects of High Yields}

Backgrounds from contaminants: It is important to use high-purity sources for the elementa! foils to avoid competing activity especially from , $11 .^{-}$, reactionsi. In particular. some iron samples were found to have too much manganese in them: hence 
the ${ }^{56} \mathrm{Fe}(\mathrm{n}, \mathrm{p})$ reaction was affected by ${ }^{55} \mathrm{Mn}\left(\mathrm{n} \cdot \gamma^{\prime}\right)$ contributions leading to spurious results.

At the high fluences of TFTR DT operation (up to $10^{12} \mathrm{n} / \mathrm{cm}^{2}$ ). relatively low masses of elemental foils are needed to rapidly obtain excellent counting statistics with relatively low deadtime on the $\mathrm{HPGe}$ detectors. A worry existed that contaminants in the activation capsules. "radding, or labeling materials could compete with the activation of low-mass foils. To measure the background. capsules without foils but with various combinations of labeling (ink and tape) and wadding were irradiated and counted. Of those components, the wadding (Kimberly Clark 34256 Wipes) was found to be the major source of contaminants. ${ }^{28} \mathrm{Al}$ radiation at $1778 \mathrm{keV}$ was seen. at a level of background equivalent to having an effective mass of silicon of 1 mgram. There is a 10 -minute half-live decay of $511-\mathrm{keV}$ radiation; this is believed to be ${ }^{13} \mathrm{~N}$ from activated air in the capsule, and it corresponds to an equivalent mass of $\leq 1.5$ mgram of copper. The capsules were counted for longer counting times as well, including irradiated capsules with the elemental foils removed. ${ }^{24} \mathrm{Na}$ radiation at $1369 \mathrm{keV}$ and $275 \mathrm{t} \mathrm{kel}$ was seen. equivalent to $0.6 \mathrm{mgram}$ of effective mass of aluminum. Another form of wadding gave much worse results, with effective masses of several milligrams: care has been taken subsequently to use only the better form of wadding. Based on these results. the elemental foils used were kept around $100 \mathrm{mgram}$ so that the contamination would be $a<1 \%$ correction.

There are two HPGe counting stations used on TFTR.' Spectra were taken on one empty counting station while an aluminum foil from a high-yield DT discharge was counted in the other. No cross-talk $\left(<10^{-5}\right)$ between the detectors was observed.

Cooling Times: With a lower operational limit of $\sim 100$ mgram mass (from background contaminants). silicon foils are "too hot" to be counted within several minutes after a high-yield DT discharge. After waiting several 2.24-minute half-lives of the reaction product (typically 10-1.5 minutes) the deadtime of the HPGe detector drops to a suitable value of below $5 \%$. With $15-20$ minutes between TFTR discharges this causes a delay in the data analysis but does not result in any continually increasing "rquene" of samples to be counted. 
For longer-lived activities (hours to davs half-life) samples are removed from the pneumatic system and "cooled" to allow the short-lived (n.i) activity to die away. Waiting $\sim 1$ hour appears sufficient for aluminum and iron: indium foils typically require up to.$j$ hours of cooling before the $336 \mathrm{keV}$ peak is insignificantly affected by Compton background of other activity.

Safety concerns about activation products and personnel dose have been considered. After DT discharges the activated air inside the pneumatic system is positively flushed into the TFTR Test Cell before capsules are returned: this places a 2-minute minimum time before counting after a DT discharge. The activation foils themselves have mRem/hour contact dose immediately after the shot from shortlived $(n, i)$ activity, especially observed in so-called "low activation" materials like vanadium or titanium. However. within typically $5-10$ minutes this activity decays to rates just similar to low-level radioactive calibration sources, and within an hour they are safe to handle for loading capsules for counting.

\section{Comparison of Different Reactions}

Elemental foils of Al. Si. $\mathrm{Cl}$ and $\mathrm{K}$ (in the form of $\mathrm{KCl}$ ). Ti. V. Cr. Fe. Co. Ni. Cu. Zr. Nb. Mo, In. W, and tu have so far been irradiated by DT discharges on TFTR. " Some of these elements feature dosimetry standard reactions that can be used to measure the fusion energy production and compared with high accuracy. Figure 1 (a) shows the cross-section is neutron energy for several standard reactions measured on TFTR. In Table I we show the measured response (measured "activated nuclei per target nuclei" (or "bits"] per source neutron) compared to the calculated response from the MCXP model ${ }^{9}$ with "default" plasma conditions used (major radius of plasma source at $2.625 \mathrm{~m}$. a gaussian radial profile with FWHM of $0.155 \mathrm{~m}$, and a Maxwellian fusion burn temperature of $17.5 \mathrm{keV}$ ). Also tabulated is the response calculated from the analytic model of Zankl $\epsilon t$ al.isee Eqn. (3) of Ref. 18) using the cross-section value ${ }^{19}$ at $14.1 \mathrm{Mel}$ and a fluence-to-yield iatio of $0.0117 \mathrm{~m}^{-2}$ for the lower tally and $0.0112 \mathrm{~m}^{-2}$ for the upper tally $2.58 \mathrm{~m}$ major radius of foil. with toroidal cut -off angle of $=90^{\circ}$. Foils requiring counting soon after a discharge are 
irradiated in the upper tally location and returned directly to the counting station: otherwise they aire irradiated in the lower tally location.

The ${ }^{3} \mathrm{Si}(\mathrm{n} . \mathrm{p})$ reaction is not a dosimetry standard. Figure $\mathbf{l}(\mathrm{b})$ shows the crosssection 15 incident neutron energy from the ACTL library. ${ }^{4}$ ENDF/B- $Y^{19}$ and as used at JET. ${ }^{20}$ Lse of the ACTL value gives agreement with the neutron yields from aluminum within $3 \%$ (see Table 1 ). While we have not run MCNP with the other tabulations. we expect the JET values to also be in general agreement: however. the E.NDF/B-V values are too low near $14 \mathrm{MeV}$.

There are some important details in analyzing some of the reactions. The $2 \pi .704$ day ${ }^{51} \mathrm{Cr}$ activity at $320 \mathrm{keV}$ must be subtracted from the initial 5.76 minute decay of ${ }^{51} \mathrm{Ti}$ at the same energy to determine the ${ }^{54} \mathrm{Cr}(n, \alpha)$ response. The ${ }^{52} \mathrm{Cr}(n, 2 \mathrm{n})^{51} \mathrm{Cr}$ response is dominated by activity from ${ }^{50} \mathrm{Cr}(\mathrm{n}, \gamma)$. Counting of nickel and cobalt foils must wait for the 9.15 hour excited state to fully decay into the 70.916 day ground state of ${ }^{58} \mathrm{Co}$. The cross-section for the reactions into both the ground and excited state must then be used.

\section{Dynamic Range}

In addition to the goal of achieving a high accuracy calibration for fusion energy production on TFTR. the second goal of the neutron activation work was to achieve linear detector operation over a large dynamic range. This is achievable by gradually: reducing the masses of the elemental foils (a factor of 20-100 from a few grams down to 100 mgrams) while allowing for some cooling time (providing typically a factor of 10 or less) while accepting greatly improved counting statistics with less counting time ( more counts in less time by factors of $10^{2}-10^{3}$ ) all while keeping the deadtime of the HPGe counter to less than $5 \%$. A six-order-of-magnitude dynamic range $(5$ orders for the same element. silicon) has been demonstrated. with the DT neutron yield per shot ranging from $10^{12}$ to over $10^{18}$. Figure 2 illustrates measurements of the $11-\mathrm{MeV}$ neutron yield using silicon and aluminum foils from a sequence of TFTR discharges. including ohmic discharges and tritium neutral beam injection. References 21 and $2-2$ show examples of comparing other detector systems and their linearity to the 
activation system. The absolute calibrations of three other neutron detection systems and their uncertainties are compared to neutron activation in Ref. $\mathbf{2 3}$.

\section{DD neutron yield in the presence of many DT neutrous}

Once tritium was injected into the TFTR vacuum vessel. some of it collected on the walls and "recycled" into the plasma on subsequent discharges. Eventually, this has led to the 14-MeV neutron emission being greater than the 2.5 -HeV neutron emission on some discharges which have no tritium injection at all. Measuring the yield of DD neutrons in the presence of a significant vield of DT neutrons is a difficult but important problem for determining the recycling coefficients. It is further important in "trace" tritium experiments. or those with low tritium beam power. It also helps constrain the relative detection efficiencies to DD and DT neutrons of fission chambers and other detectors that respond to both types of neutrons.

As shown in Figure 1 the ${ }^{115} \operatorname{In}\left(\mathrm{n}, n^{1}\right)^{115 m}$ In cross-section actually peaks near 2.5 $\mathrm{MeV}$ and decreases a factor of over 3 by $14-\mathrm{MeV}$. The calculated activation response for this reaction is a factor of $R_{D T}^{\mathrm{In}} / R_{D D}^{\mathrm{In}}=2.69 / 6.35=0.42$ lower for $D T$ neutrons than DD. This difference in response is used to measure the DD emission in these mixed DD/DT discharges by subtracting off the DT response measured using (typically) aluminum activation that only responds to the DT component. For a measured activation of aluminum $H^{\mathrm{Al}}$ and of indium $H^{\mathrm{ln}}$. the DT and DD yields are

$$
\begin{aligned}
& Y_{D T}=\frac{H^{A I}}{R_{D T}^{A 1}} \\
& Y_{D D}=\frac{H^{\mathrm{Ln}}}{R_{D D}^{\ln }}-\frac{R_{D T}^{\ln }}{R_{D D}^{\ln }} Y_{D T}
\end{aligned}
$$

where $R_{D T}^{A l}$. $R_{D T}^{\ln }$. and $R_{D D}^{\mathrm{In}}$ are the response coefficients to DT and DD neutrons for aluminum and indium. Because $R_{D T}^{\mathrm{ln}} / R_{D D}^{\mathrm{ln}}$ is a relatively small number the contribution to the DD yield from the DT measurement is not as important as for detectors with more sensitivity to DT neutrons. The relative uncertainty of the $\mathrm{DD} / \mathrm{DT}$ response ratio (the 0.42 factor) primarily comes from uncertainties in the cross-sections at the two energies and secondarily to the possible different behavior ot the scattered contribution io the response at ine itferent inergies. However. the primary uncertainty irom inaccuracies in geometric modeling tend to cancel in this 
technique. Thus the response ratio is probably accurate to $\sim \pm 4 \%$. With each of the measured activations divided by response accurate to $\pm 9 \%$. the $Y_{D D}$ can be determined to a fractional error $\epsilon_{D D}$ of

$$
\epsilon_{D D}=\sqrt{(9 \%(1+\rho))^{2}+\left(9 \%^{2}+4 \%^{2}\right) \rho^{2}}
$$

where $\rho=\left\langle R_{D T}^{\ln } / R_{D D}^{\ln }\right\rangle\left\langle Y_{D T} / Y_{D D}\right\rangle$. As $\rho$ tends to zero the accuracy is just that for a simple DD measurement of $9 \%$ : for equal yields or $\rho=0.42$ the DD yield in known to about $13 \%$ accuracy: for $\rho=4$ or 9.5 times more DT neutrons than DD the accuracy climbs to $63 \%$.

\section{Acknowledgments}

This work was performed under DOE Contracts W-it05-EVG-36 and DE-AC0276CH03073. We thank ken loung of PPPL for his support for our collaborations on TFTR, and Anil humar of ECLA for informative conversations. 


\section{References}

'O. X. Jarvis et al.. Fusion Tech. 20. 265 i199!1.

2.). Kälne et al.. Nucl. Fusion 28, 1291 (1988).

35. Conroy. O. ‥ Jarvis, G. Sadler. and G. B. Huxtable. Xucl. Fusion 28. 212i (1988).

†I. Pillon and A. Vannucci. Sucl. Instrum. Methods Phys. Research A255. 188 $(1987)$.

${ }^{5} \mathrm{C}$. IV. Barnes et al. Nicl. Fusion (1994). (to be submitted).

${ }^{`}$ E. B. Nieschmidt. Rev. Sci. Instrum. 57. 175i (1986).

'C. WV. Barnes et al. Rev. Sci. Instrum. 61, 3190 (1990).

${ }^{8}$ G. Sadler. O. N. Jarvis. P. van Belle. and M. Pillon. Rev. Sci. Instrum. 61, 3175 (1990).

${ }^{9}$ C. W. Barnes. A. R. Larson. and A. L. Roquemore. Fusion Tech. (1994), (to be submittedi.

${ }^{10}$ Standard source from Analytics. Inc. of telanta. G.A.

"G. A. Kivrala. Rev. Sci. Instrum. 63. 4768 (1992).

12F. Biggs and R. Lighthill. Technical Report SAXDST-0070-CC.34. Sandia Report. 1990.

${ }^{13} \mathrm{E}$. Browne and R. B. Firestone. Table of Radioactive lsotopes. John Wiley and Sons. Jew lork. 1986.

14.1I. A. Gardner and R. J. Howerton. ACTL: Eraluated neutron activation crosssection library - evaluation techniques and reaction index. Technical Report ICRL-50400. Vol. 18. Lawrence Lirermore Sational Laboratory 1978.

15. Nagner et al.. Eraluation of cross sections for líf important netutron-dosimetry

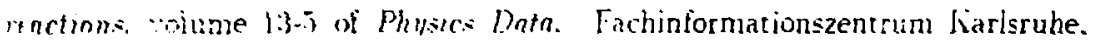
!990. ISS. 93+4-3+01. 
${ }^{26} \mathrm{~J}$. F. Briesmeister. IIC.NP - a general monte carlo n-particle transport code version ta. Technicál Repōit L.i-12623-.M. Los Alamos National Laboratory. 1993.

IF. Kumar. M. A. Abdou. H. W. Kugel. C. W. Barnes, and M. J. Loughlin. Radioactivity measurements of ITER materials using TFTR D-T neutron feld. in Proceedings of the Third International Symposium on Fusion . Nuclear Technology, LCLA. 1994.

${ }^{18}$ G. Zankl. J. D. Strachan. R. Lewis. II. Pettus. and J. Schmotzer. Nucl. Instrum. Methods 185. 321 (1981).

${ }^{19} \mathrm{Y}$. McLane. C. L. Dunford. and P. F. Rose. Vistron Cross Sections, volume 2: Neutron Cross Section Curves. Academic Press. Inc.. New York, fourth edition. 1988.

${ }^{20} \mathrm{M}$. Loughlin and M. Rapisarda. 1992, private communication.

${ }^{21}$ E. Ruskor. W. W. Heidbrink, H. H. Duong. A. L. Roquemore, and J. D. Strachan. Rev. Sci. Instrum. (1994), (this conference).

${ }^{22}$ J. Strachan et al.. Rev. Sci. Instrum. (1994). (this conference).

${ }^{23}$ L. C. Johnson et al.. Rer. Sci. Instrum. (1994). (this conference). 
Table 1: Measured Response of Activation Reactions Compared to Calculated Responses

\begin{tabular}{|c|c|c|c|c|}
\hline \multirow[b]{2}{*}{ Reaction } & \multirow{2}{*}{$\begin{array}{r}\text { \# of } \\
\text { Shots }\end{array}$} & \multicolumn{3}{|c|}{ Response $\left(10^{-31}\right.$ Hits per neutron $)$} \\
\hline & & Measured & Zankl & MCNP \\
\hline \multicolumn{5}{|c|}{ Lower Tally (1.039 $\mathrm{m}$ above midplane) } \\
\hline${ }^{2 \pi} \mathrm{Al}(\mathrm{n} . \alpha)^{24} \mathrm{Na}$ & 33 & $1.54 \pm 0.12$ & 1.45 & 1.54 \\
\hline${ }^{50} \mathrm{Cr}(n, 2 \pi){ }^{49} \mathrm{Cr}$ & 1 & 0.20 & 0.12 & 0.13 \\
\hline${ }^{52} \mathrm{Cr}(\mathrm{n} \cdot \mathrm{p})^{52} \mathrm{~V}$ & 1 & 1.2 & 1.05 & 1.15 \\
\hline${ }^{54} \mathrm{Cr}(\mathrm{n} . \alpha)^{51} \mathrm{Ti}$ & 1 & 0.16 & 0.14 & 0.15 \\
\hline${ }^{56} \mathrm{Fe}(n, p)^{56} \mathrm{Mn}$ & 5 & $1.56 \pm 0.04$ & 1.34 & 1.44 \\
\hline${ }^{58} \mathrm{Ni}(\mathrm{n} \cdot \mathrm{p})^{58} \mathrm{Co}$ & 3 & $6.0 \pm 0.1$ & 1.92 & 6.49 \\
\hline${ }^{88} \mathrm{Ni}(\mathrm{n} \cdot 2 \mathrm{n})^{57} \mathrm{Ni}$ & 3 & 0.28 & 0.30 & 0.29 \\
\hline$\left.{ }^{59} \mathrm{Coln} \cdot 2 \mathrm{n}\right)^{58} \mathrm{Co}$ & 3 & 8.7 & 7.9 & 3.0 \\
\hline${ }^{90} \mathrm{Zr}(\mathrm{n} \cdot 2 \mathrm{n})^{89} \mathrm{Zr}$ & 4 & $7.4 \pm 0.3$ & 7.68 & 7.53 \\
\hline${ }^{115} \ln \left(\mathrm{n} . \mathrm{n} i^{115 \mathrm{~m}} \ln \right.$ & 1 & 3.0 & $0.7 t$ & 2.69 \\
\hline \multicolumn{5}{|c|}{ [pper Tally (1.088 $\mathrm{m}$ above midplane) } \\
\hline${ }^{23} \mathrm{Si}(\mathrm{n} . \mathrm{p})^{27} \mathrm{Al}$ & 2.5 & $3.38 \pm 0.28$ & 3.33 & $3 . \pm 7$ \\
\hline${ }^{30} \operatorname{Si}(\mathrm{n}, \alpha)^{2 \pi} \mathrm{MIg}$ & 2 & $0.88 \pm 0.08$ & 1.00 & 0.98 \\
\hline${ }^{5+} \mathrm{Fe}(\mathrm{n}, 2 \mathrm{n})^{53} \mathrm{Fe}$ & 1 & 0.026 & 0.049 & 0.075 \\
\hline
\end{tabular}




\section{Figures}

FIG. 1. Veutron activation cross-section ts energy: (a) . Al. Si. Cr. Fe. .ii. Zr. and In reactions. all from the ACTL library as used in the MCNP modeling. (b) ${ }^{28} \mathrm{Si}(\mathrm{n} . \mathrm{p})$ cross-section from the ACTL. JET. and EXDF/B-l' tabulations.

FIG. 2. DT neutron vield is IFTR shot number for a sequence of discharges illustrating the large dynamic range of the neutron activation system. Circles are aluminum foils. and squares are for silicon. 


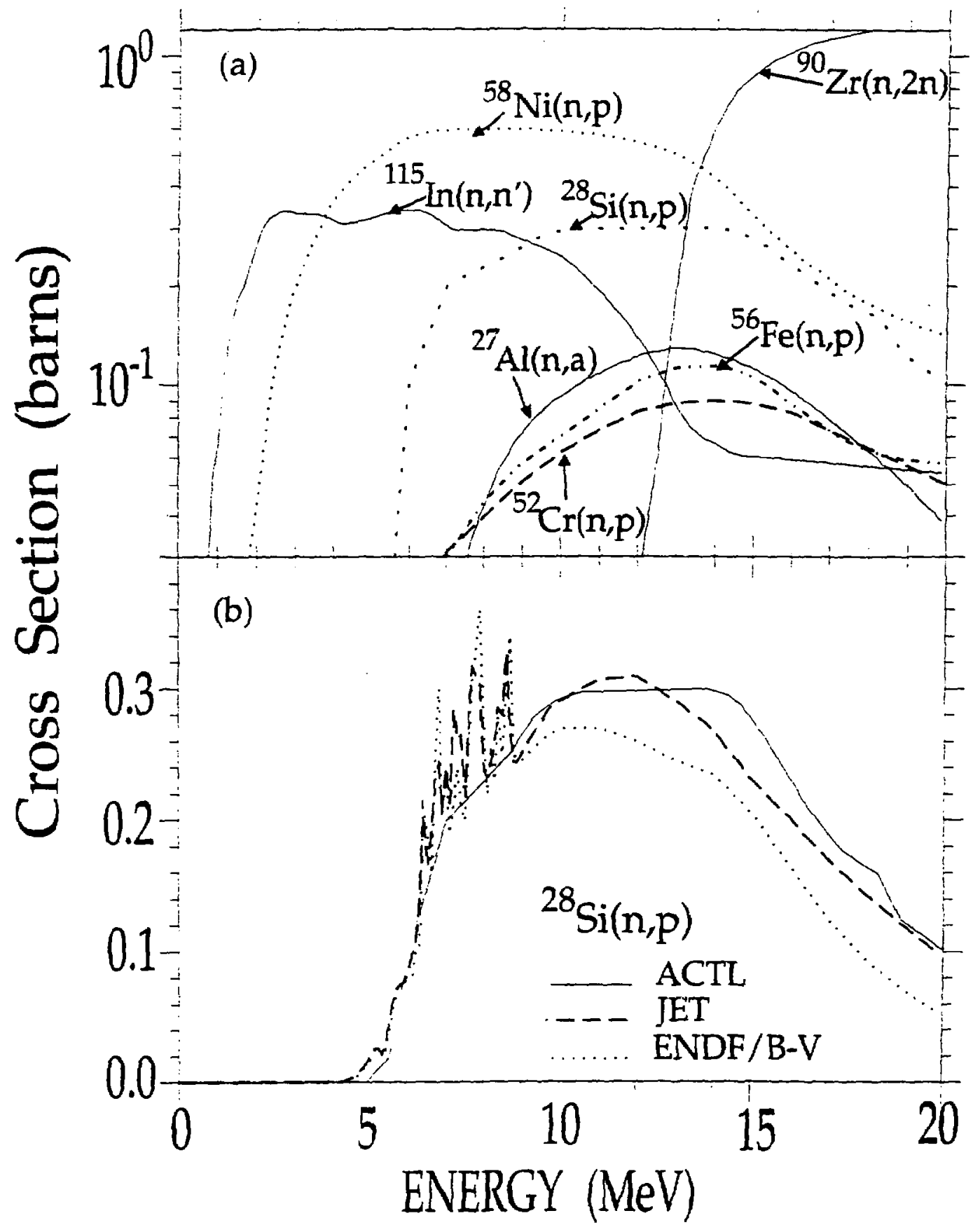




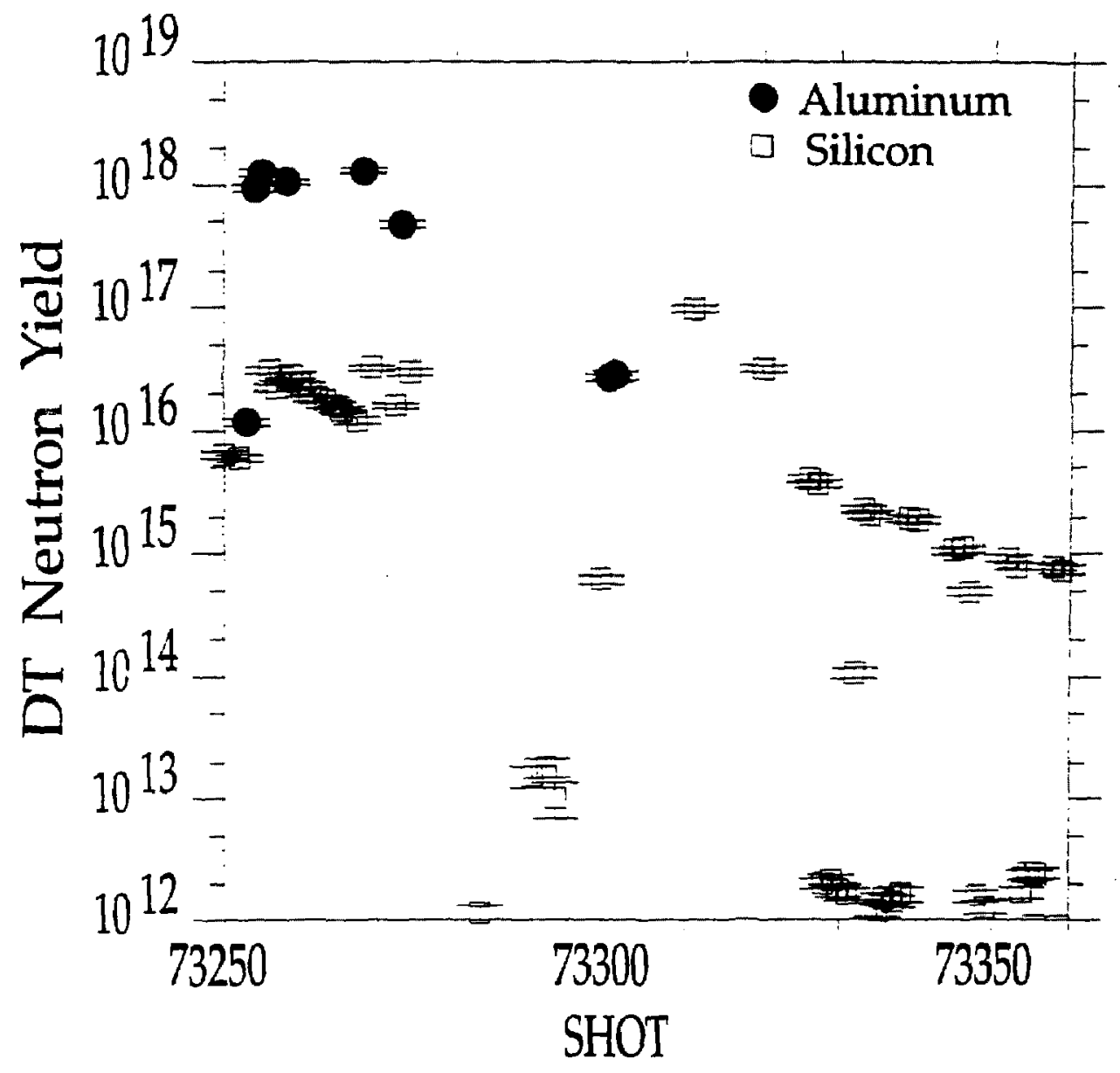


Dr. F. Peoloni, Univ, of Wollongong. AUSTRALIA

Prof. R.C. Cross, Univ. of Sydney, AUSTRALIA

Plesma Posearch Leb., Australian Nat. UriY., AUSTRALIA

Prof. I.R. Jones, Flinders Univ, AUSTRALIA

Prof. F. Cep, Inst. for Theoreties Physics, AUSTRIA

Prot. M. Heindter, Institut tur Theoreticche Physik, AUSTRIA

Prof. M. Goossens, Astronomisch Instibut, BELGIUM

Ecole Poyale Mitrior, Lab. de Phy. Plasmas, BELGUUM

Commission-Europear, DG. XII-Fusion Prop., BELGIUM

Prof. R. Bouciqué, Rijksuniversitgit Gent, BELGIUM

Dr. P.H. Sakanaka, Instituto Fisica, BRUZIL

Prof. Dr. I.C. Nascimento, Instituso Fisica, Sao Paulo, BPAZIL instituto Nacional Do Poequisas Espacieis-INPE, BRAZIL Documents Office, Atomic Energy of Canada Lit., CANADA Ms. M. Morin, CCFWTokamak de Varennes, CANADA Dr. M.P. Bechynski, MPB Technologies, Inc., CANADA Dr. H.M. Skarsgard, Univ. of Saskatchewan, CANADA Prof. J. Teichmann, Univ. of Montreal, CANADA Prof. S.R. Sreenivasan, Univ. of Calgary, CANADA Prot. T.W. Johnston, INAS-Energie, CANADA Dr. R. Bolton, Centre canadien de fusion magnétique, CANADA Dr. C.R. James, Univ, of Aberta, CANADA

Dr. P. Lukdc, Komensktho Universzita, CZECHO-SLOVAKIA The Librarian, Culham Laboratory. ENGLAND Library. R61, Rutherford Appleton Laboratory, ENGLAND Mrs. S.A. Hukchinson, JET Library. ENGLAND Dr. S.C. Shama, Univ of South Pacific, FIJI ISLANDS P. Mathonen, Univ. of Helsinki, FINLAND Prof. M.N. Bussac, Ecole Polytochnique, FRANCE C. Mouttel, Lab. de Physique des Milieux lonisess, FRANCE J. Padat CEN/CADARACHE - Bat 506, franCE Prot. E. Economou, Univ, of Crete, GREECE Ms. C. Rinni, Univ. of loaming, GREECE Preprint Lbrery. Hungarian Acadamy of Sci.. HUNGARY Dr. B. DasGupta, Saha inst. of Nuclear Physics, INDIA Dr. P. Kaw, Inst. for Plasma Research, INDIA Dr. P. Roseneu, Iereed Inst. of Technology, ISPAEL Librarien, Intemational Center for Theo Phytics, ITALY Miss C. De Palo, Ascocizziono EURATOM-ENEA, ITALY Dr. G. Crosso, Istiuto di Fisica del P1asma, ITALY Prof. G. Rostengni, Istituso Gas lonizzati Del Cnr, ITALY
Dr. H. Yamato, Toshiba Res $\triangle$ Devel Conter, JAPAN

Pral. I. Kawakami, Hiroshima Univ., JAPAN

Prof. K. Nishikawa, Hiroshima Univ., JAPAN

Librarian, Naka Fusion Research Establishment, JAERI, JAPAN

Director, Japan Atomic Energy Research Inst., JAPAN

Prot. S. Itoh, Kyushu Univ., JAPAN

Pesearch Inlo. Cr., National Instit for Fusion Science, JAPAN

Prof. S. TanakB, Kyoto Univ., JAPAN

Library, Kyoto Univ., JAPAN

Prof. N. Inouv, Univ. of Tokyo, JAPAN

Secretary. Plasma Section, Electrotechnical Lab., JAPAN

Dr. O. Mitarai, Kumamoto Inst. of Technology. JAPAN

Dr. G.S. Loe, Koroa Basic Sci. Ctr., KOAEA

J. Hyeon-Sook, Korea Alomic Energy Research Inst., KOREA

D.l. Choi, The Korea Adv. Inst. of Sci. Tech., KOREA

Prof. B.S. Liley, Univ. of Waikato. NEW ZEALAND

Inst of Physics, Chinese Acad Sci PEOPLE'S REP. OF CHINA Library, Inst. of Plasma Physies, PEOPLE'S REP. OF CHINA Tsinghua Univ. Litrary, PEOPLE'S REPUBLIC OF CHINA Z. Li, S.W. Inst Physics, PEOPLE'S REPUBLIC OF CHINA Prof. J.A.C. Cabral, Instituto Superior Tecnico, PORTUGAL Prot. M.A. Hellberg. Univ. of Natal, S. AFRICA

Prof. D.E. Kim, Pohang Inst. of Sci. \& Tech., SO. KOREA

Prof. C.I.E.M.A.T. Fusion Division Librany. SPAIN

Dr. L. Stenflo, Univ. of UMEA. SWEDEN

Library. Royal inst. of Technology. SWEDEN

Prof. H. Writhelmson, Chalmers Univ. of Tech., SWEDEN

Centre Phys. Des Plasmas, Ecole Polytech, SWITZERLAND Bibliothook, Inst. Voor Plasma-Fysica, THE NETHERLANDS Asst. Prol. Dr. S. Cakir, Middle East Tech. Univ., TURKEY Dr. V.A. Gukhikh,Sci. Res. Inst. Eloctrophys.l Apparatus, USSA Dr. D.D. Ryutov, Siberian Branch of Academy of Sri., USSR Dr. G.A. Ekserv, I.Y. Kurchatov Inst., USSA Librarian. The Ukr.SSR Acedemy of Sciences, USSR Dr. L. Rt. Kovizhnykh, inst. of General Physics, USSR Kemiorsechungsaniege GmbH. Zentrabibliothek, W. GEPMANY Bibliothek, Inst. Fur Plasmaforschung, W. GEAMANY Prof. K. Schinder, Rutr-Universitat Bochum, W. GEAMANY Dr. F. Wogner, (ASDEX), Max-Planck-Institut, W. GERMANY Librerion, Max-Planck-Institut, W. GERMANY 